\title{
Sequentially Catalyzed Three-Component Masuda-Suzuki-Sono- gashira Synthesis of Fluorescent 2-Alkynyl-4-(7-azaindol-3-yl) pyrimidines: Three Palladium-Catalyzed Processes in a One-Pot Fashion
}

\author{
Daniel Drießen \\ Lukas Biesen \\ Thomas J. J. Müller* (1) \\ Institut für Organische Chemie und Makromolekulare \\ Chemie, Heinrich-Heine-Universität Düsseldorf, Uni- \\ versitätsstraße 1, 40225 Düsseldorf, Germany \\ Thomas]J.Mueller@hhu.de
}

Published as part of the Cluster The Power of Transition Metals: An Unending Well-Spring of New Reactivity

Received: 31.03 .2020

Accepted after revision: 08.05.2020

Published online: 29.05 .2020

DOI: 10.1055/s-0040-1707818; Art ID: st-2020-b0180-c

Abstract The Masuda-Suzuki-Sonogashira sequence efficiently unites, in a one-pot fashion, a borylation, an arylation, and an alkynylation in the sense of a sequentially Pd-catalyzed three-component reaction to give fluorescent 2-alkynyl-4-(7-azaindol-3-yl) pyrimidines in yields of $24-83 \%$ (14 examples). Time-dependent density-functional theory calculations supported the electronic structure of the longest wavelength absorption bands, revealing that this novel consecutive three-component synthesis opens an efficient access to alkynyl meriolins, a novel class of potential inducers of apoptosis.

Key words arylation, alkynylation, borylation, fluorescence, multicomponent reaction, meriolins

Sequentially Pd-catalyzed processes ${ }^{1}$ open the unique possibility of using an initially employed catalyst system for more than a single transformation in a one-pot fashion. Besides providing catalyst economy, the fine tuning of substrates additionally sets the stage for transition-metal-mediated syntheses of heterocyclic scaffolds, in the sense of multicomponent reactions ${ }^{2}$ involving multiple catalytic steps. In recent years, we have established a sequential Pdcatalyzed process called the Masuda borylation-Suzuki coupling $^{3}$ for concise one-pot syntheses of unsymmetrically substituted biheteroaryl compounds (Scheme 1). This sequence has been successfully applied to syntheses of natural products and biologically active compounds. ${ }^{3 \mathrm{f}-\mathrm{h}, 4}$ Particularly interesting are 7-azaindole derivatives, considered to be truncated hybrids of meridianins [2-amino-4-(indol-3- yl)pyrimidines and variolins], which have shown considerable potential as inhibitors of protein kinases. ${ }^{5}$ We recently reported the application of the Masuda borylation-Suzuki coupling sequence for the synthesis of novel meriolin derivatives as potential inducers of rapid apoptosis in tumor cell lines. ${ }^{3 \mathrm{~h}}$
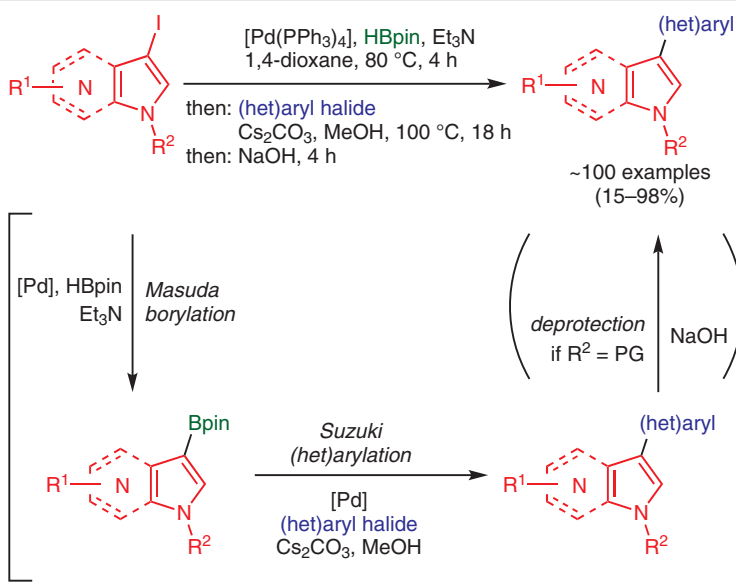

$(15-98 \%)$

Scheme 1 One-pot Masuda borylation-Suzuki arylation synthesis of unsymmetrically biheteroaryls

On the basis of our experience in applying the $\mathrm{Pd}-\mathrm{Cu}$ catalyst systems in sequentially catalyzed one-pot process$\mathrm{es}^{6}$ and our general interest in transition-metal-mediated multicomponent synthesis of heterocycles, ${ }^{2}$ we surmised that the Masuda-Suzuki sequence might be extended to a 
process involving three consecutive Pd-catalyzed steps. By employing 2,4-dichloropyrimidine as a suitable substrate for site-selective cross-coupling, ${ }^{7}$ we assumed that after Masuda borylation and Suzuki arylation at the 4-position, a selective final Sonogashira alkynylation ${ }^{8}$ at the 2-position might lead to novel derivatives of meriolins. We reasoned that concatenation of three catalytic processes - borylation, heteroarylation, and alkynylation - in a one-pot fashion without further Pd catalyst loading might provide a sequence that would be of practical use. Here, we report the development of a one-pot sequential Pd-catalyzed MasudaSuzuki-Sonogashira sequence for the synthesis of meriolin derivatives, together with an experimental and computational study on the photophysical properties of selected derivatives.

Starting from the corresponding 7-azaindoles, by a onepot two-step protocol involving iodination and tosylation, we prepared the two $\mathrm{N}$-protected 3-iodo-7-azaindoles 1a and $\mathbf{1 b}$ in yields of 94 and 99\%, respectively, as suitable substrates for our proposed sequence [for details, see the Supporting Information (SI)]. ${ }^{\text {h }}$ With $\mathrm{N}$-tosyl-3-iodo-7-azaindole (1a), pinacolylborane, and 2,4-dichloropyrimidine (2) the Masuda-Suzuki coupling of dihalide $\mathbf{2}$ to give the 2chloropyrimidyl meriolin derivative $\mathbf{3} \mathbf{a}$ or $\mathbf{3 b}$ (protected or unprotected, respectively) in a selective manner was optimized by changing the base, temperature, and reaction time (Table 1). Unlike our previous one-pot synthesis of apoptosis-inducing meriolins, ${ }^{3 \mathrm{~h}}$ and due to the highly nucleophilic character of alcoholic carbonate solutions, the cosolvent for Suzuki coupling was changed to a mixture of 1,2-dimethoxyethane ${ }^{9}$ and water.

Even with water as cosolvent, cesium carbonate still represented the preferred base compared with sodium carbonate (Table 1, entries 1 and 2). Interestingly, with a reaction time of 42 hours for the Suzuki coupling step, cleavage of the tosyl group proceeded in situ to furnish the deprotected 2-chloropyrimidyl meriolin $\mathbf{3 b}$. Upon lowering the reaction temperature for the Suzuki coupling step to $80^{\circ} \mathrm{C}$, the tosyl group remained attached, permitting isolation of the $N$-tosylated product $\mathbf{3 a}$ in high yield (entries 3-6). A slight increase in the amount of pinacolylborane in the Masuda step led to an excellent yield of the $\mathrm{N}$-tosyl-2-chloropyrimidyl meriolin 3a (entry 7). The selective formation of a single isomer was evident from the presence of a single set of signals in the NMR spectra, in agreement with the Pdcatalyzed 4-alkynylation of compound 2. ${ }^{10}$ Furthermore, the connectivity of the 2-chloropyrimidyl-substituted derivative 3a was unambiguously supported by 2D-ROESYNMR spectroscopy (for details, see the SI).

The selective Masuda-Suzuki formation of the 2-chloropyrimidyl-substituted derivative $3 a$ set the stage for concatenation of a concluding alkynylation. In a consecutive onepot fashion, starting from $\mathrm{N}$-tosyl 3-iodo-7-azaindoles $\mathbf{1}$, pinacolylborane, and 2,4-dichloropyrimidine (2), and upon addition of an alkyne $\mathbf{4}$ and a catalytic amount of copper io-
Table 1 Optimization of the Masuda-Suzuki Synthesis of 2-Chloropyrimidyl Meriolin Derivatives 3

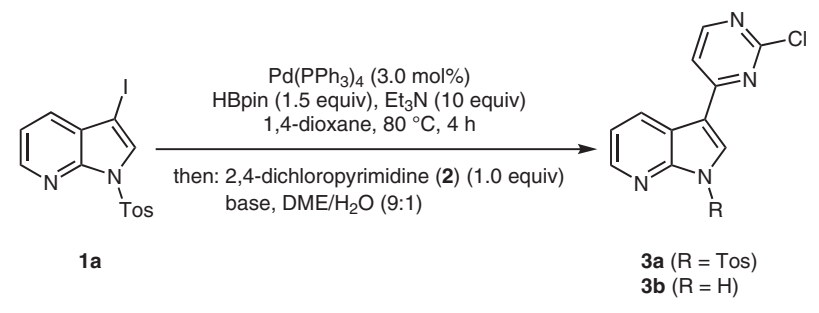

\begin{tabular}{llcccc}
\hline Entry & Base (equiv) & Temp $\left({ }^{\circ} \mathrm{C}\right)$ & Time (h) & Product & Yield (\%) \\
\hline 1 & $\mathrm{Na}_{2} \mathrm{CO}_{3}(2.5)$ & 100 & 42 & $\mathbf{3 b}$ & 30 \\
2 & $\mathrm{Cs}_{2} \mathrm{CO}_{3}(2.5)$ & 100 & 42 & $\mathbf{3 b}$ & 65 \\
3 & $\mathrm{Cs}_{2} \mathrm{CO}_{3}(2.5)$ & 80 & 42 & $\mathbf{3 a}$ & 82 \\
4 & $\mathrm{Cs}_{2} \mathrm{CO}_{3}(2.5)$ & 80 & 16 & $\mathbf{3 a}$ & 70 \\
5 & $\mathrm{Cs}_{2} \mathrm{CO}_{3}(2.5)$ & 60 & 20 & $\mathbf{3 a}$ & 70 \\
6 & $\mathrm{Cs}_{2} \mathrm{CO}_{3}(2.5)$ & 80 & 20 & $\mathbf{3 a}$ & 86 \\
7 & $\mathrm{Cs}_{2} \mathrm{CO}_{3}(2.5)$ & 80 & 18 & $\mathbf{3 a}$ & 94 \\
\hline
\end{tabular}

a HBpin (1.7 equiv) was used in the Masuda borylation step.

dide, the corresponding 2-alkynyl-4-(7-azaindol-3-yl)pyrimidines $\mathbf{5}$ were isolated after single flash chromatography in moderate to good yields (Scheme 2).

Whereas copper iodide and the appropriate alkyne were added at this stage, no additional triethylamine or palladium catalyst needed to be added to the reaction mixture. Interestingly, a loading of $3.0 \mathrm{~mol} \%$ of tetrakis(triphenylphosphine)palladium( 0 ) proved to be sufficient to catalyze all three reaction steps in this novel Masuda-Suzuki-Sonogashira sequence. The structures of the products $\mathbf{5}$ were unambiguously supported by NMR spectroscopy, mass spectrometry, and the elemental composition as determined by combustion analysis.

The isolated yields of the title compounds 5 ranged from 24 to $83 \%$, which equates to an average yield per bondforming step in this consecutive three-component process of $62-94 \%$. A variety of alkynes 4, ranging from electron-deficient to electron-rich aromatic or aliphatic alkynes, as well as alkynes containing unprotected alcohol (5h) or TIPS groups (51 and $\mathbf{5 n}$ ), were well tolerated, highlighting the breadth of diversity of potential reactants. With 3-iodo-4methoxy-7-azaindole (1b) as a substrate, targets substituted in the azaindole moiety were synthesized uneventfully (e.g., 5n).

All the 2-alkynyl-4-(7-azaindol-3-yl) pyrimidines 5 produced intense blue-to-green emissions on excitation with UV light $\left(\lambda_{\text {exc }}=365 \mathrm{~nm}\right)$. We therefore recorded the absorption and emission spectra of 12 compounds (Table 2). Almost all compounds 5 displayed similar absorption behaviors with intense maxima between 293 and $296 \mathrm{~nm}$; the molar decadic absorption coefficients $\varepsilon$ were in the range 23100-43900 $\mathrm{L} \mathrm{mol}^{-1} \mathrm{~cm}^{-1}$ for aliphatic substituents and 


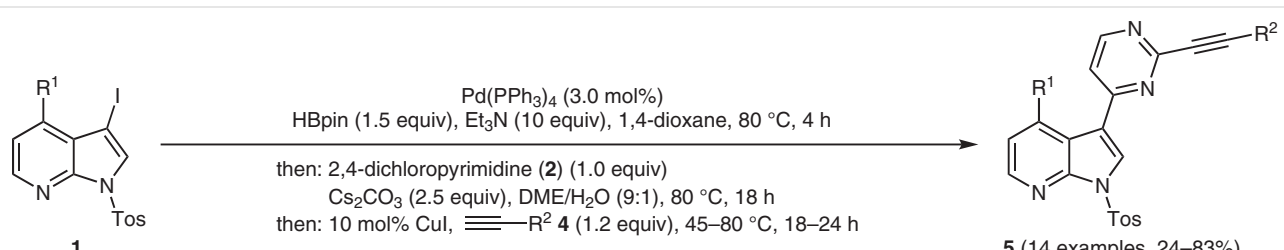
then: $10 \mathrm{~mol} \% \mathrm{Cul}, \equiv \mathrm{R}^{2} 4$ (1.2 equiv), $45-80^{\circ} \mathrm{C}, 18-24 \mathrm{~h}$
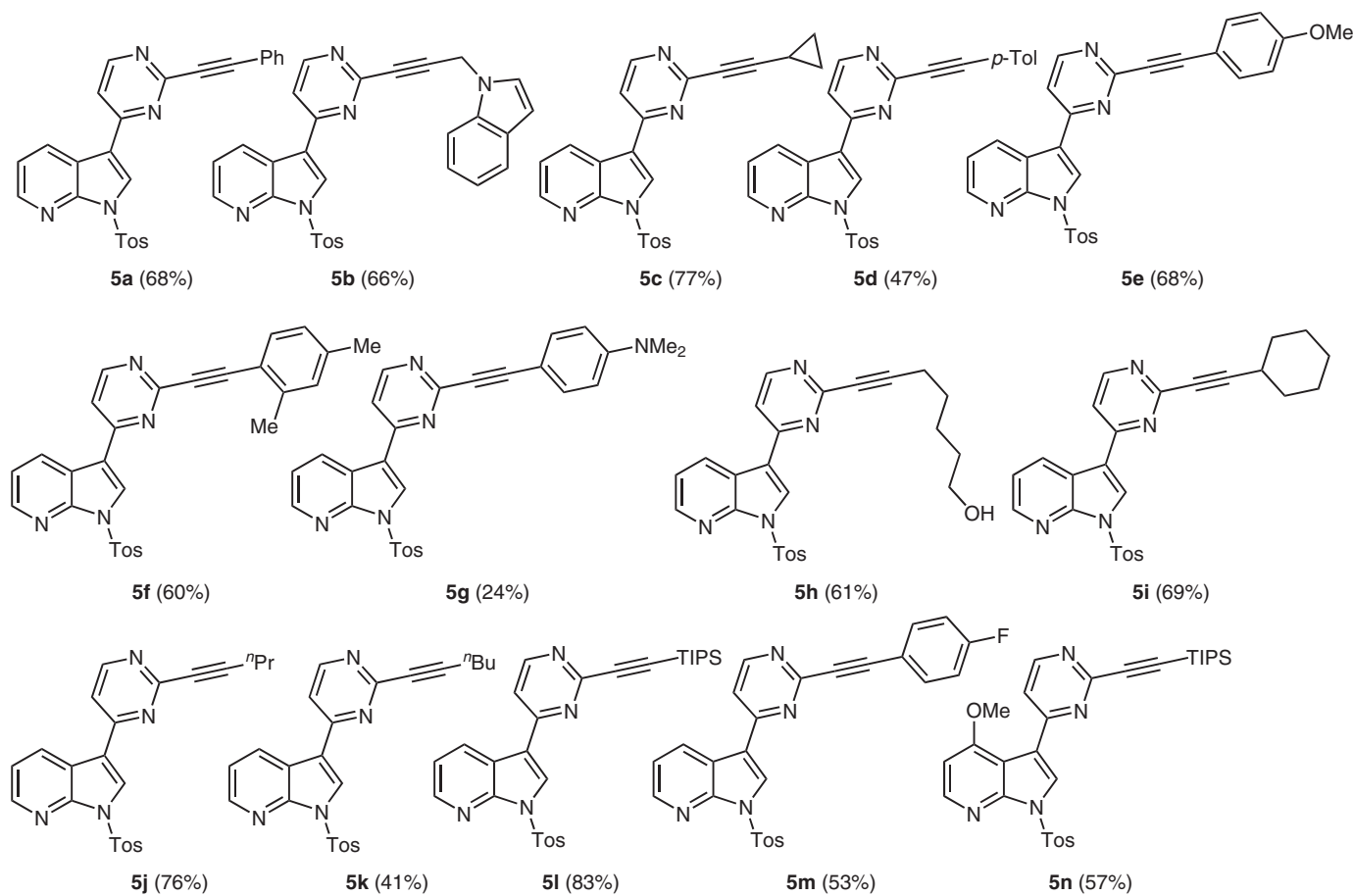

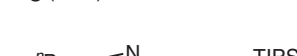

5 h $(61 \%)$ $5 \mathbf{i}(69 \%)$

5j $(76 \%)$ $5 \mathbf{k}(41 \%)$

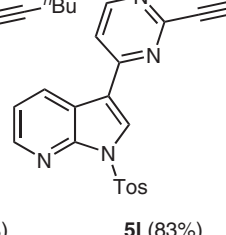
$5 \mathrm{I}(83 \%)$

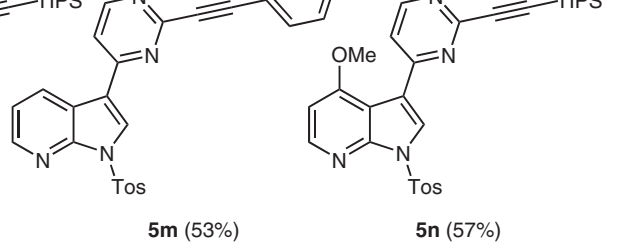

Scheme 2 Consecutive three-component Masuda borylation-Suzuki arylation-Sonogashira alkynylation synthesis of 2-alkynyl-4-(7-azaindol-3-yl)pyrimidines 5

48000-77000 L mol-1 $\mathrm{cm}^{-1}$ for aromatic substituents. Notably, the two strong donor-substituted derivatives $\mathbf{5 e}$ and $\mathbf{5 g}$ possessed red-shifted absorption maxima at 306 and 366 $\mathrm{nm}$, respectively. Interestingly, the emission maxima were almost identical irrespective of the nature of the substituent $\mathrm{R}^{2}$, with exception of $p$-(dimethylamino)phenyl- (5g), cyclohexyl- (5i), and propyl-substituted derivatives (5j). All other compounds fluoresced with emission maxima at about $447 \mathrm{~nm}$. The Stokes shifts were remarkably high and amounted to 10300 to $11900 \mathrm{~cm}^{-1}$, with exception of compound $5 \mathbf{g}\left(8300 \mathrm{~cm}^{-1}\right)$.

The normalized absorption and emission spectra of the conjugated $p$-phenyl-substituted derivatives $\mathbf{5 a}, \mathbf{5 d}, \mathbf{5 e}$, and 5e are almost superimposable (for details, see Figure S1, SI ), indicating they have quite similar electronic structures. However, for the $p$-(dimethylamino)phenyl-substituted derivative $\mathbf{5 g}$ in particular, in comparison to the phenyl- (5a), cyclohexyl- (5i), and propyl-substituted (5j) derivatives, the significant redshifts in the absorption (366 nm) and emission ( $525 \mathrm{~nm}$ ) maximum can be ascribed to a change in the dominant underlying chromophore (Figure 1). Compound $\mathbf{5 g}$ consists of a strongly polarizable donor-acceptor chro- mophore with the $p$-(dimethylamino)phenyl moiety as an electron donor and the pyrimidyl unit as an acceptor. This chromophore axis is significantly different from the transition dipole orientation of the other derivatives, which are presumably oriented along the 7-azaindole-pyrimidine axis.

To achieve a qualitative understanding of the electronic structure of the absorption spectrum of compounds $\mathbf{5}$, time-dependent density-functional theory (TDDFT) calculations for compounds $5 \mathbf{a}\left(\mathrm{R}^{2}=\mathrm{Ph}\right)$ and $\mathbf{5 g}\left(\mathrm{R}^{2}=p\right.$ $\mathrm{Me}_{2} \mathrm{NC}_{6} \mathrm{H}_{4}$ ) were performed with the PBE functional and the $6-31 \mathrm{G}^{* *}$ basis set as implemented in Gaussian 09. ${ }^{11}$ The calculated longest wavelength absorption bands are best represented by vertical Franck-Condon transitions, as represented by the Kohn-Sham frontier molecular orbitals (FMOs) HOMO and LUMO (Figure 2), and these are in reasonably good agreement with the experimentally determined absorption bands (5a: calcd $287 \mathrm{~nm}$; experimental 295 nm; 5g: calcd 365 nm; experimental 366 nm).

However, the character of these transitions is substantially different. Whereas for compound $\mathbf{5 a}\left(\mathrm{R}^{2}=\mathrm{Ph}\right)$, coefficient densities of both the HOMO and LUMO are mainly lo- 
Table 2 Summary of the UV/Vis-Absorption- and Emission-Specific Properties of the Alkyne-Substituted Meriolin Derivatives 6 in Dichloromethane at $293 \mathrm{~K}$

\begin{tabular}{|c|c|c|c|c|}
\hline Compound & $\mathrm{R}^{2}$ & Absorption $\lambda_{\max , \text { abs. }}(\mathrm{nm})(\varepsilon)\left(\mathrm{L} \cdot \mathrm{mol}^{-1} \cdot \mathrm{cm}^{-1}\right)^{\mathrm{a}}$ & Emission $\lambda_{\max , e m}(n m)^{b}$ & Stokes shift $\Delta v^{\sim}\left(\mathrm{cm}^{-1}\right)^{c}$ \\
\hline $5 a$ & $\mathrm{Ph}$ & $295(48900)$ & 447 & 11600 \\
\hline $5 b$ & indol-1-ylmethyl & $293(27800)$ & 447 & 11800 \\
\hline $5 c$ & cyclopropyl & $293(23100)$ & 447 & 11700 \\
\hline 5d & $4-\mathrm{Tol}$ & $295(48400)$ & 447 & 11600 \\
\hline $5 e$ & $4-\mathrm{MeOC}_{6} \mathrm{H}_{4}$ & $306(49900)$ & 447 & 10300 \\
\hline $5 f$ & $2,4-\mathrm{Me}_{2} \mathrm{C}_{6} \mathrm{H}_{3}$ & $294(63200)$ & 447 & 11600 \\
\hline $5 g$ & $4-\mathrm{Me}_{2} \mathrm{NC}_{6} \mathrm{H}_{4}$ & $366(61700)$ & 525 & 8300 \\
\hline $5 \mathrm{~h}$ & $4-\mathrm{HO}\left(\mathrm{CH}_{2}\right)_{4}$ & $296(26000)$ & 448 & 11500 \\
\hline $5 i$ & Cy & $296(32800)$ & 430 & 10600 \\
\hline $5 \mathbf{j}$ & $\operatorname{Pr}$ & $296(24800)$ & 429 & 10500 \\
\hline 51 & TIPS & $298(43900)$ & 447 & 11200 \\
\hline $5 m$ & 4- $-\mathrm{FC}_{6} \mathrm{H}_{4}$ & $293(76700)$ & 447 & 11900 \\
\hline
\end{tabular}

$\mathrm{a}[\mathbf{5}]=10^{-5} \mathrm{M}$.

$\mathrm{b}[\mathbf{5}]=10^{-7} \mathrm{M}, \lambda_{\text {exc }}=\lambda_{\text {max,abs }}$

c $\Delta v^{\sim}=1 / \lambda_{\max , a b s}-1 / \lambda_{\max , \text { em }}\left(\mathrm{cm}^{-1}\right)$.

calized on the 2-(phenylethynyl)pyrimidin-4-yl part, the strong donor part of compound $\mathbf{5 g}\left(\mathrm{R}^{2}=p-\mathrm{Me}_{2} \mathrm{NC}_{6} \mathrm{H}_{4}\right)$ creates a dominant push-pull chromophore in which the HOMO and LUMO coefficient densities are spatially separated from each other and overlap only on the central pyrimidyl core. Whereas the HOMO coefficient density is mostly localized on the [ $p$-(dimethylamino)phenyl]ethynyl part, the LUMO coefficient density is localized in the 3-pyrimid-4-yl-7-azaindole moiety. This spatial separation accounts for a significant charge-transfer character of the longest wavelength absorption band of structure $\mathbf{5 g}$. In the ex-

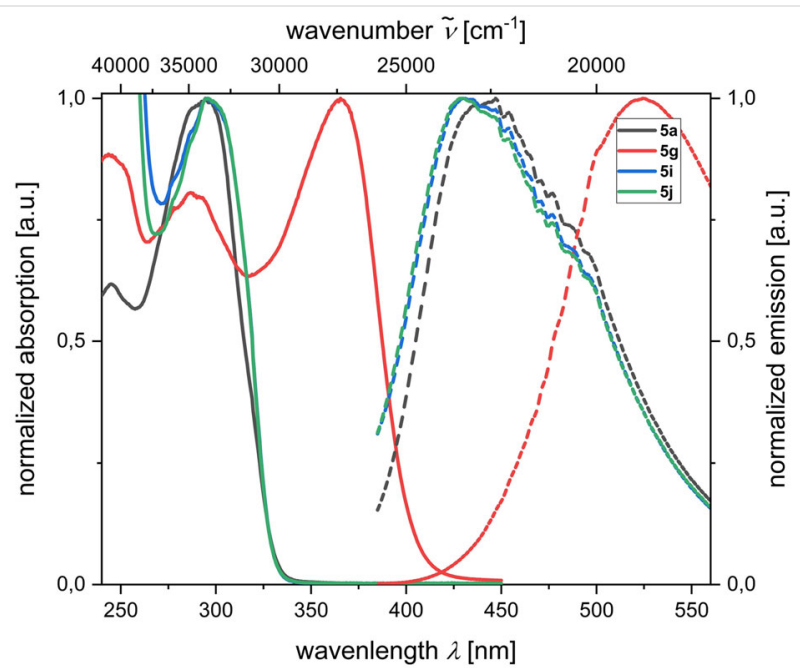

Figure 1 Normalized absorption (solid lines; $[\mathbf{5}]=10^{-5} \mathrm{M}$ ) and emission (dashed lines; $[\mathbf{5}]=10^{-7} \mathrm{M}$ ) spectra of selected derivatives $\mathbf{5}$ in dichloromethane at $293 \mathrm{~K}\left(\lambda_{\mathrm{exc}}=\lambda_{\max , \mathrm{abs}}\right)$ perimental spectrum, the strong bathochromic shift is accompanied by a strong absorption coefficient $\varepsilon$ (62000 $\mathrm{L} \mathrm{mol}^{-1} \mathrm{~cm}^{-1}$ ).

In conclusion, a novel sequentially Pd-catalyzed MasudaSuzuki-Sonogashira synthesis of 2-alkynyl-4-(7-azaindol-3yl)pyrimidines (i.e., alkynyl meriolin derivatives) was developed in the form of a consecutive three-component reaction. ${ }^{12}$ This novel process not only concatenates three catalytic reactions - borylation, arylation, and alkynylation - efficiently and efficaciously in a single vessel without further addition of the initial palladium catalyst source, but also

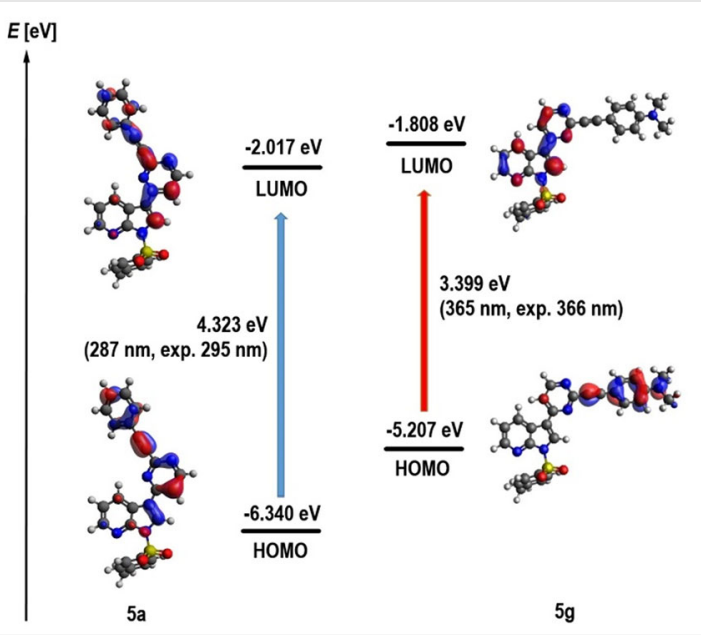

Figure 2 TDDFT-computed Kohn-Sham FMOs of dyes $\mathbf{5 a}$ and $\mathbf{5 g}$, representing contributions of the TDDFT-computed longest wavelength

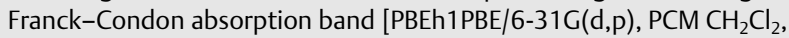
isosurface value at 0.04 a.u.] 
provides easy access to interesting novel fluorophores. The broad variety of the alkynes used underlines the fact that variable functionalities can be introduced. Whereas strong donor substituents furnish significantly red-shifted fluorophores with excitations near the visible region, silyl alkynyl moieties permit tagging for further functionalization. The combination of the 7-azaindole substructure with functional alkynyl sidechains with substantial fluorescence suggests that this concise synthetic concept might be useful for protein-target-fishing strategies and for confocal microscopy in biophysical analytics. Expansion of the methodological scope of this novel one-pot process and its application to the development of new functional materials and probes is currently underway.

\section{Funding Information}

This work was supported by the Deutsche Forschungsgemeinschaft (GRK 2158) and the Fonds der Chemischen Industrie.

\section{Supporting Information}

Supporting information for this article is available online at https://doi.org/10.1055/s-0040-1707818.

\section{References and Notes}

(1) (a) Lessing, T.; Müller, T. Appl. Sci. 2015, 5, 1803. (b) Müller, T. J. J. Top. Organomet. Chem. 2006, 19, 149.

(2) D'Souza, D. M.; Müller, T. J. J. Chem. Soc. Rev. 2007, 36, 1095.

(3) (a) Baudoin, O.; Guénard, D.; Guéritte, F. J. Org. Chem. 2000, 65, 9268. (b) Baudoin, O.; Cesario, M.; Guénard, D.; Guéritte, F. J. Org. Chem. 2002, 67, 1199. (c) Penhoat, M.; Levacher, V.; Dupas, G. J. Org. Chem. 2003, 68, 9517. (d) Broutin, P. E.; Čerňa, I.; Campaniello, M.; Leroux, F.; Colobert, F. Org. Lett. 2004, 6, 4419. (e) Abreu, A. S.; Ferreira, P. M. T.; Queiroz, M.-J. R. P.; Ferreira, I. C. F. R.; Calhelha, R. C.; Estevinho, L. M. Eur. J. Org. Chem. 2005, 2951. (f) Merkul, E.; Schäfer, E.; Müller, T. J. J. Org. Biomol. Chem. 2011, 9, 3139. (g) Tasch, B. O. A.; Merkul, E.; Müller, T. J. J. Eur. J. Org. Chem. 2011, 4532. (h) Drießen, D.; Stuhldreier, F.; Frank, A.; Stark, H.; Wesselborg, S.; Stork, B.; Müller, T. J. J. Bioorg. Med. Chem. 2019, 27, 3463.

(4) (a) Tasch, B. O. A.; Bensch, L.; Antovic, D.; Müller, T. J. J. Org. Biomol. Chem. 2013, 11, 6113. (b) Tasch, B. O. A.; Antovic, D.; Merkul, E.; Müller, T. J. J. Eur. J. Org. Chem. 2013, 4564.

(5) (a) Bettayeb, K.; Tirado, O. M.; Marionneau-Lambot, S.; Ferandin, Y.; Lozach, O.; Morris, J. C.; Mateo-Lozano, S.; Drueckes, P.; Schachtele, C.; Kubbutat, M. H.; Liger, F.; Marquet, B.; Joseph, B.; Echalier, A.; Endicott, J. A.; Notario, V.; Meijer, L. Cancer Res. 2007, 67, 8325. (b) Echalier, A.; Bettayeb, K.; Ferandin, Y.; Lozach, O.; Clément, M.; Valette, A.; Liger, F.; Marquet, B.; Morris, J. C.; Endicott, J. A.; Joseph, B.; Meijer, L. J. Med. Chem. 2008, 51, 737. (c) Hammond, M.; Washburn, D. G.; Hoang, H. T.; Manns, S.; Frazee, J. S.; Nakamura, H.; Patterson, J. R.; Trizna, W.; Wu, C.; Azzarano, L. M.; Nagilla, R.; Nord, M.; Trejo, R.; Head, M. S.; Zhao, B.; Smallwood, A. M.; Hightower, K.; Laping, N. J.; Schnackenberg, C. G.; Thompson, S. K. Bioorg. Med. Chem. Lett. 2009, 19, 4441. (d) Hong, S.; Lee, S.; Kim, B.; Lee, H.;
Hong, S.-S.; Hong, S. Bioorg. Med. Chem. Lett. 2010, 20, 7212. (e) Jarry, M.; Lecointre, C.; Malleval, C.; Desrues, L.; Schouft, M.T.; Lejoncour, V.; Liger, F.; Lyvinec, G.; Joseph, B.; Loaëc, N.; Meijer, L.; Honnorat, J.; Gandolfo, P.; Castel, H. Neuro-Oncology (Cary, NC U. S.) 2014, 16, 1484. (f) Singh, U.; Chashoo, G.; Khan, S. U.; Mahajan, P.; Nargotra, A.; Mahajan, G.; Singh, A.; Sharma, A.; Mintoo, M. J.; Guru, S. K.; Aruri, H.; Thatikonda, T.; Sahu, P.; Chibber, P.; Kumar, V.; Mir, S. A.; Bharate, S. S.; Madishetti, S.; Nandi, U.; Singh, G.; Mondhe, D. M.; Bhushan, S.; Malik, F.; Mignani, S.; Vishwakarma, R. A.; Singh, P. P. J. Med. Chem. 2017, 60, 9470. (g) Zhang, H.-C.; Ye, H.; Conway, B. R.; Derian, C. K.; Addo, M. F.; Kuo, G.-H.; Hecker, L. R.; Croll, D. R.; Li, J.; Westover, L.; Xu, J. Z.; Look, R.; Demarest, K. T.; Andrade-Gordon, P.; Damiano, B. P.; Maryanoff, B. E. Bioorg. Med. Chem. Lett. 2004, 14, 3245. (h) Wucherer-Plietker, M.; Merkul, E.; Müller, T. J. J.; Esdar, C.; Knöchel, T.; Heinrich, T.; Buchstaller, H.-P.; Greiner, H.; Dorsch, D.; Finsinger, D.; Calderini, M.; Bruge, D.; Grädler, U. Bioorg. Med. Chem. Lett. 2016, 26, 3073.

(6) For recent examples of the use of the Pd/Cu-Sonogashira catalyst system for sequentially catalyzed heterocycle synthesis in a one-pot fashion, see: (a) Niesobski, P.; Nau, J.; May, L.; Moubsit, A.-E.; Müller, T. J. J. Dyes Pigm. 2020, 173. (b) Niesobski, P.; Martínez, I. S.; Kustosz, S.; Müller, T. J. J. Eur. J. Org. Chem. 2019, 2019, 5214. (c) Niesobski, P.; Klukas, F.; Berens, H.; Makhloufi, G.; Janiak, C.; Müller, T. J. J. J. Org. Chem. 2018, 83, 4851. (d) Götzinger, A. C.; Theßeling, F. A.; Hoppe, C.; Müller, T. J. J. Org. Chem. 2016, 81, 10328.

(7) (a) Langer, P.; Ehlers, P.; Reimann, S.; Erfle, S.; Villinger, A. Synlett 2010, 1528. (b) Akrawi, O. A.; Hussain, M.; Langer, P. Tetrahedron Lett. 2011, 52, 1093. (c) Langer, P.; Hamdy, A.; Khaddour, Z.; Villinger, A. Synlett 2015, 26, 2527. (d) Reeves, E. K.; Humke, J. N.; Neufeldt, S. R. J. Org. Chem. 2019, 84, 11799.

(8) (a) Sonogashira, K.; Tohda, Y.; Hagihara, N. Tetrahedron Lett. 1975, 16, 4467. (b) Negishi, E.; Anastasia, L. Chem. Rev. 2003, 103, 1979. (c) Chinchilla, R.; Nájera, C. Chem. Rev. 2007, 107, 874. (d) Reimann, S.; Ehlers, P.; Ohlendorf, L.; Langer, P. Org. Biomol. Chem. 2017, 15, 1510. (e) Malik, I.; Ahmed, Z.; Reimann, S.; Ali, I.; Villinger, A.; Langer, P. Eur. J. Org. Chem. 2011, 2011, 2088.

(9) Huang, S.; Li, R.; Connolly, P. J.; Emanuel, S.; Middleton, S. A. Bioorg. Med. Chem. Lett. 2006, 16, 4818.

(10) Deng, X.; Mani, N. S. Org. Lett. 2006, 8, 269.

(11) Frisch, M. J.; Trucks, G. W.; Schlegel, H. B.; Scuseria, G. E.; Robb, M. A.; Cheeseman, J. R.; Scalmani, G.; Barone, V.; Mennucci, B.; Petersson, G. A.; Nakatsuji, H.; Caricato, M.; Li, X.; Hratchian, H. P.; Izmaylov, A. F.; Bloino, J.; Zheng, G.; Sonnenberg, J. L.; Hada, M.; Ehara, M.; Toyota, K.; Fukuda, R.; Hasegawa, J.; Ishida, M.; Nakajima, T.; Honda, Y.; Kitao, O.; Nakai, H.; Vreven, T.; Montgomery, J. A. Jr.; Peralta, J. E.; Ogliaro, F.; Bearpark, M.; Heyd, J. J.; Brothers, E.; Kudin, K. N.; Staroverov, V. N.; Kobayashi, R.; Normand, J.; Raghavachari, K.; Rendell, A.; Burant, J. C.; Iyengar, S. S.; Tomasi, J.; Cossi, M.; Rega, N.; Millam, J. M.; Klene, M.; Knox, J. E.; Cross, J. B.; Bakken, V.; Adamo, C.; Jaramillo, J.; Gomperts, R.; Stratmann, R. E.; Yazyev, O.; Austin, A. J.; Cammi, R.; Pomelli, C.; Ochterski, J. W.; Martin, R. L.; Morokuma, K.; Zakrzewski, V. G.; Voth, G. A.; Salvador, P.; Dannenberg, J. J.; Dapprich, S.; Daniels, A. D.; Farkas, Ö.; Foresman, J. B.; Ortiz, J. V.; Cioslowski, J.; Fox, D. J. Gaussian 09, Gaussian, Inc., Wallingford, 2016.

(12) Products 5a-m; General Procedure 7-azaindole 1a (398 mg, $1.00 \mathrm{mmol})$ and $\left(\mathrm{Ph}_{3} \mathrm{P}\right)_{4} \mathrm{Pd}(35.0 \mathrm{mg}$, $0.03 \mathrm{mmol}$ ) were placed in a dry screw-cap vessel equipped with a magnetic stirrer bar. The vessel was evacuated and refilled with argon three times, then anhyd 1,4-dioxane (5.00 
$\mathrm{mL}$ ) was added and the resulting mixture was degassed with argon for $10 \mathrm{~min}$. Dry $\mathrm{Et}_{3} \mathrm{~N}(1.40 \mathrm{~mL}, 10.0 \mathrm{mmol})$ and 4,4,5,5tetramethyl-1,3,2-dioxaborolane $(0.25 \mathrm{~mL}, 1.70 \mathrm{mmol})$ were successively added and the mixture was stirred in a preheated oil bath at $80^{\circ} \mathrm{C}$ for $4 \mathrm{~h}$ then cooled to r.t. (water bath). Dry 1,2dimethoxyethane $(9.00 \mathrm{~mL})$ and $\mathrm{H}_{2} \mathrm{O}(1.00 \mathrm{~mL})$ were added, and the mixture was stirred at r.t. for $10 \mathrm{~min}$. 2,4-Dichloropyrimidine (2; $149 \mathrm{mg}, 1.00 \mathrm{mmol})$ and $\mathrm{Cs}_{2} \mathrm{CO}_{3}(823 \mathrm{mg}, 2.50 \mathrm{mmol})$ were then added, and the mixture was stirred in a preheated oil bath at $80^{\circ} \mathrm{C}$ for $18 \mathrm{~h}$. When the Suzuki coupling was complete, the mixture was cooled to r.t. (water bath), and $\mathrm{CuI}(19.0 \mathrm{mg}$, $0.10 \mathrm{mmol})$ and the appropriate alkyne $4(1.20 \mathrm{mmol})$ were added. The mixture was stirred at $45-80{ }^{\circ} \mathrm{C}$ for $18 \mathrm{~h}$. When the Sonogashira coupling was complete (TLC), the mixture was cooled to r.t. (water bath), the solvents were removed in vacuo, and the residue was absorbed onto Celite. After purification by chromatography (silica gel, hexane-acetone), the product was sonicated in hexane-acetone (95:5) for further purification. The solvent was removed and the residue was dried in vacuo at 70 ${ }^{\circ} \mathrm{C}$ for $42 \mathrm{~h}$.

\section{1-[(4-Methylphenyl)sulfonyl]-3-[2-(phenylethynyl)pyrimi-} din-4-yl]-1H-pyrrolo[2,3-b]pyridine (5a)

The final Sonogashira step was carried out at $80{ }^{\circ} \mathrm{C}$ for $18 \mathrm{~h}$ to give a yellow solid; yield: $310 \mathrm{mg}(0.68 \mathrm{mmol}, 68 \%)$; $\mathrm{mp} 200.3-$ $202.7^{\circ} \mathrm{C} ; R_{f}=0.48\left(\mathrm{CH}_{2} \mathrm{Cl}_{2}\right.$-acetone, $\left.6: 4\right)$.

IR (neat): 3379 (w), 3107 (w), 3090 (w), 3026 (w), 2918 (w), 2218 (w), 1593 (m), 1570 (s), 1555 (w), 1533 (s), 1491 (m), 1479 (w), 1425 (w), 1398 (s), 1381 (m), 1368 (s), 1335 (w), $1302(\mathrm{~m}), 1262(\mathrm{~m}), 1244(\mathrm{~m}), 1186(\mathrm{~s}), 1171(\mathrm{~s}), 1155(\mathrm{~s}), 1123$ (w), $1075(\mathrm{w}), 1036(\mathrm{~m}), 1017(\mathrm{~m}), 999(\mathrm{w}), 961(\mathrm{~s}), 918(\mathrm{w})$, $883(\mathrm{~m}), 866(\mathrm{w}), 849(\mathrm{w}), 837(\mathrm{~m}), 822(\mathrm{~m}), 802(\mathrm{~m}), 775(\mathrm{~s})$, 756 (s), 732 (s), $675(\mathrm{~s}), 654(\mathrm{~s}), 633(\mathrm{w}) \mathrm{cm}^{-1} .{ }^{1} \mathrm{H}$ NMR $(600$ MHz, DMSO- $\left.d_{6}\right): \delta=2.35\left(\mathrm{~s}, 3 \mathrm{H}, \mathrm{CH}_{3}\right), 7.44-7.54(\mathrm{~m}, 6 \mathrm{H}, \mathrm{CHAr})$, $7.72\left(\mathrm{~d},{ }^{3} J_{\mathrm{HH}}=6.7 \mathrm{~Hz}, 2 \mathrm{H}, \mathrm{CHAr}\right), 8.09\left(\mathrm{~d},{ }^{3} J_{\mathrm{HH}}=8.5 \mathrm{~Hz}, 2 \mathrm{H}\right.$, CHAr), $8.23\left(\mathrm{~d},{ }^{3} J_{\mathrm{HH}}=5.4 \mathrm{~Hz}, 1 \mathrm{H}, \mathrm{CHAr}\right), 8.48\left(\mathrm{dd},{ }^{3} J_{\mathrm{HH}}=4.7 \mathrm{~Hz}\right.$, $\left.{ }^{4} J_{\mathrm{HH}}=1.6 \mathrm{~Hz}, 1 \mathrm{H}, \mathrm{CHAr}\right), 8.85\left(\mathrm{~d},{ }^{3} J_{\mathrm{HH}}=5.4 \mathrm{~Hz}, 1 \mathrm{H}, \mathrm{CHAr}\right), 8.88$ (dd, $\left.{ }^{3} J_{\mathrm{HH}}=8.0 \mathrm{~Hz},{ }^{4} J_{\mathrm{HH}}=1.6 \mathrm{~Hz}, 1 \mathrm{H}, \mathrm{CHAr}\right), 9.03(\mathrm{~s}, 1 \mathrm{H}, \mathrm{CHAr})$. ${ }^{13} \mathrm{C}$ NMR $\left(150 \mathrm{MHz}\right.$, DMSO- $\left.d_{6}\right): \delta=21.1\left(\mathrm{CH}_{3}\right), 86.2\left(\mathrm{C}_{\text {quat }}\right), 88.6$ $\left(\mathrm{C}_{\text {quat }}\right), 115.5\left(\mathrm{C}_{\text {quat }}\right), 116.4(\mathrm{CH}), 119.8(\mathrm{CH}), 120.4\left(\mathrm{C}_{\text {quat }}\right), 120.5$ $\left(\mathrm{C}_{\text {quat }}\right), 128.0(\mathrm{CH}), 129.0(\mathrm{CH}), 129.2(\mathrm{CH}), 130.1(\mathrm{CH}), 130.2$ $(\mathrm{CH}), 131.7(\mathrm{CH}), 132.2(\mathrm{CH}), 134.0\left(\mathrm{C}_{\text {quat }}\right), 145.7(\mathrm{CH}), 146.2$ $\left(\mathrm{C}_{\text {quat }}\right), 146.9\left(\mathrm{C}_{\text {quat }}\right), 152.0\left(\mathrm{C}_{\text {quat }}\right), 157.8(\mathrm{CH}), 159.8\left(\mathrm{C}_{\text {quat }}\right)$. EI MS: $\mathrm{m} / \mathrm{z}(\%)=450(21)[\mathrm{M}+], 386(100)\left[\mathrm{C}_{21} \mathrm{H}_{14} \mathrm{~N}_{4} \mathrm{O}_{2} \mathrm{~S}^{+}\right], 385(36), 296$ (11), 268 (12), 267 (19), 155 (13) $\left[\mathrm{C}_{7} \mathrm{H}_{7} \mathrm{O}_{2} \mathrm{~S}^{+}\right], 142$ (14), 141 (12) $\left[\mathrm{C}_{9} \mathrm{H}_{5} \mathrm{~N}_{2}^{+}\right], 127(11), 114(14)\left[\mathrm{C}_{9} \mathrm{H}_{6}^{+}\right], 91(90)\left[\mathrm{C}_{7} \mathrm{H}_{7}{ }^{+}\right], 65(14)$ $\left[\mathrm{C}_{5} \mathrm{H}_{5}{ }^{+}\right]$. Anal. Calcd for $\mathrm{C}_{26} \mathrm{H}_{18} \mathrm{~N}_{4} \mathrm{O}_{2} \mathrm{~S}(450.5)$ : C, 69.32; H, 4.03; N, 12.44; S, 7.12. Found: C, 69.11; H, 3.75; N, 12.19; S, 7.31. 